\title{
Interactive comment on "Global Annual Mean Atmospheric Histories, Growth Rates and Seawater Solubility Estimations of the Halogenated Compounds HCFC-22, HCFC-141b, HCFC-142b, HFC-134a, HFC-125, HFC-23, PFC-14 and PFC-116" by Pingyang Li et al.
}

Anonymous Referee \#4

Received and published: 27 September 2018

The comment was uploaded in the form of a supplement:

https://www.ocean-sci-discuss.net/os-2018-89/os-2018-89-RC4-supplement.pdf

Interactive comment on Ocean Sci. Discuss., https://doi.org/10.5194/os-2018-89, 2018. 